\title{
Penetration of topical, oral, and combined administered ofloxacin into the subretinal fluid
}

\author{
Osman Çekiç, Cosar Batman, Ümit Yasar, Yüksel Totan, Nursabah E Basci, \\ Atilla Bozkurt, Orhan Zilelioglu, S Oguz Kayaalp
}

\begin{abstract}
Aims-To assess the subretinal fluid (SRF) levels of ofloxacin following topical, oral or combined administration.

Methods-31 patients undergoing conventional retinal reattachment surgery were randomly assigned to three groups. Nine patients received topical ofloxacin, 11 patients received oral ofloxacin, and the other 11 patients received combined administration. Collected SRF samples were analysed for drug level by using high performance liquid chromatography.

Results-SRF drug levels after oral and combined administration were significantly higher than that after topical administration $(p=0.0002$ and $p=0.0002$, respectively) while there was no significant difference between oral and combined administration $(p=0.0844)$.

Conclusions-Ocular bioavailability of ofloxacin in SRF after oral and combined administration is equivalent. The addition of oral ofloxacin to topical therapy increased drug SRF penetration sixfold.

(Br F Ophthalmol 1999;83:1183-1185)
\end{abstract}

Ofloxacin is a fluoroquinolone antibiotic with rapid bactericidal activity interfering with DNA gyrase of bacteria. ${ }^{1}$ It has a high oral bioavailability and excellent tissue penetration. ${ }^{1}{ }^{2}$ Its favourable pharmacokinetic properties also make it useful in ophthalmic infections in the form of a topical $0.3 \%$ solution. $^{3-5}$

Penetration of topical, systemic, or combined ofloxacin into cornea, aqueous, and vitreous humour has already been studied. ${ }^{6-13}$ However, no published result was found with regard the subretinal fluid (SRF) level of the drug.

The aim of this study was to determine the SRF concentration of ofloxacin following different type of applications by using a sensitive and reliable method described by Basci et al. ${ }^{14}$

Materials and methods

Thirty one patients undergoing conventional retinal reattachment surgery were selected for the study. Nine patients (mean age 38.5 years; five male and four female), starting 6 hours before surgery, received 2 drops of $0.3 \%$ ofloxacin solution every 30 minutes for the first 3 hours and hourly instillation for the next 3 hours. Eleven patients (mean age 40.5 years; six male and five female) received a single oral dose of $400 \mathrm{mg}$ ofloxacin 8 hours before surgery. The other 11 patients (mean age 37 years, five male and six female) received a combination of those applications. Drug administration was done by a nurse to ensure compliance.

SRF samples were obtained as described by Lesk et $a l^{15}$ at the sclerotomy drainage site. Samples were stored immediately in a freezer at $-70^{\circ} \mathrm{C}$. All the patients had a uninflammed cornea, intact crystalline lens, and posterior capsule. Exclusion criteria included the presence of a fresh vitreous haemorrhage, age less than 18 years, pregnancy, diabetes mellitus, topical or systemic antibiotic or any drug that may interfere with ofloxacin use during 1 week before enrolment, allergy to quinolones, history of central nervous system, renal, or hepatic diseases. Written informed consent was obtained from each patient, and the study was approved by the ethics committee of SSK Ankara Eye Hospital, Ankara, Turkey.

High performance liquid chromatography (HPLC) grade methanol and acetonitrile were obtained from J T Baker (Phillipsburg, NJ, USA) and analytical grade citric acid and pipemidic acid from Sigma (St Louis, MO, USA). The ophthalmic solution of ofloxacin used contained benzalkonium chloride $(0.005 \%)$, hydrochloric acid, sodium hydroxide $(\mathrm{pH}$ approximately 6.4 ), and sterile water as inactive ingredients.

Stock solutions of ofloxacin $(1 \mathrm{mg} / \mathrm{ml})$ and pipemidic acid $(1 \mathrm{mg} / \mathrm{ml})$ were prepared in hydrochloric acid $(0.01 \mathrm{~N})$ and sodium hydroxide $(0.2 \mathrm{M})$, respectively. Standard solutions of ofloxacin containing pipemidic acid (1 $\mu \mathrm{g} / \mathrm{ml}$ ) were prepared as internal standard by diluting the stock solutions of ofloxacin.

Ofloxacin was measured by using an HPLC method that involves direct injection of the samples. The chromatography system consisted of a Varian 9002 solvent delivery system (Varian Associates Inc, Lexington, MA, USA), Varian 9100 autosampler, Waters 470 scanning fluorescence detector (Waters Chromatography, Milford, MA, USA), and Waters 746 data 
Table 1 Subretinal fluid ofloxacin concentrations $(\mu \mathrm{g} / \mathrm{ml})$ in treatment groups

\begin{tabular}{llllll}
\hline Patient No & $\begin{array}{l}\text { Topical } \\
\text { ofloxacin }\end{array}$ & Patient No & $\begin{array}{l}\text { Oral } \\
\text { ofloxacint }\end{array}$ & Patient No & $\begin{array}{l}\text { Topical+oral } \\
\text { ofloxacin } \neq\end{array}$ \\
\hline 1 & 0.16 & 1 & 0.94 & 1 & 1.87 \\
2 & 0.34 & 2 & 1.13 & 2 & 4.78 \\
3 & 0.73 & 3 & 1.29 & 3 & 2.29 \\
4 & 0.61 & 4 & 3.65 & 4 & 1.11 \\
5 & 0.29 & 5 & 2.16 & 5 & 1.56 \\
6 & 0.32 & 6 & 0.98 & 6 & 3.41 \\
7 & 0.29 & 7 & 1.02 & 7 & 1.18 \\
8 & 0.41 & 8 & 2.12 & 8 & 3.01 \\
9 & 0.33 & 9 & 0.99 & 9 & 4.02 \\
& & 10 & 1.11 & 10 & 2.88 \\
Mean (SEM) & $0.39(0.06)$ & Mean (SEM) & $1.60(0.26)$ & Mean (SEM) & $2.47(0.38)$ \\
\end{tabular}

*Two drops of $0.3 \%$ solution every 30 minutes for 3 hours and every 60 minutes for the next 3 hours before surgery.

†A single dose $400 \mathrm{mg} 8$ hours before surgery.

$\ddagger$ A single dose $400 \mathrm{mg} 8$ hours before surgery and two drops of $0.3 \%$ solution every 30 minutes for 3 hours and every 60 minutes for the next 3 hours before surgery.

module. The separation was performed on a Novapak C18 cartridge column $(100 \times 8 \mathrm{~mm}$ internal diameter, particle size $4 \mu \mathrm{m}$, Waters Chromatography) compressed in a Radial-Pak cartridge holder (RCM $8 \times 10$, Waters Chromatography) in conjunction with a precolumn module (Guard-Pak, Waters Chromatography). The method utilised a mobile phase composed of a mixture of methanolacetonitrile- $0.4 \mathrm{M}$ citric acid (3:1:10, vol/vol/ vol) with a flow rate of $1 \mathrm{ml} / \mathrm{min}$ at ambient temperature. The column effluent was monitored with fluorescence detection at $290 \mathrm{~nm}$ (excitation) and $500 \mathrm{~nm}$ (emission). Drug concentrations were determined against a calibration curve constructed from standard ofloxacin concentrations, and calculated from peak area values.

Kruskal-Wallis analysis of variance (ANOVA) and Mann-Whitney $U$ test were performed to compare data.

\section{Results}

Table 1 shows SRF levels of ofloxacin in the groups. There was a statistically significant difference among groups ( $p=0.0001)$ (Fig 1). The concentration of ofloxacin in SRF produced by topical administration was significantly lower than the oral and combined group ( $p=0.0002$ and $p=0.0002$, respectively). The difference between concentrations of ofloxacin in SRF obtained with oral and combined

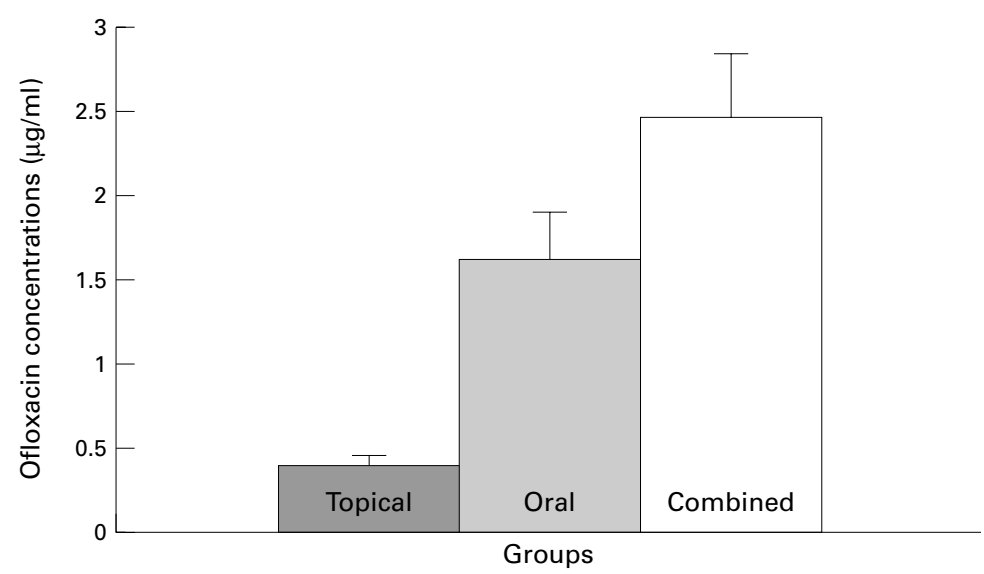

Figure 1 Comparison of subretinal fluid levels of ofloxacin obtained after different modes of administration. administration was not statistically significant $(\mathrm{p}=0.0844)$.

\section{Discussion}

Topical ofloxacin penetrates ocular structures better than the other fluoroquinolones. ${ }^{6-9}$ Its useful clinical concentration in tear film layer lasts longer after topical application. ${ }^{516}$ As topical ofloxacin is formulated at a $\mathrm{pH}$ of 6.4 , it is very soluble and its increased solubility may explain its prolonged effective tear levels after topical application. ${ }^{11}$

In this study, topical ofloxacin yielded a mean of $0.39 \mu \mathrm{g} / \mathrm{ml}$ concentration in SRF which was comparable with vitreal ofloxacin level following topical administration. ${ }^{12} 13$ Donnenfeld et $a l^{12}$ found a mean vitreous level of $0.37 \mu \mathrm{g} / \mathrm{ml}$ following topical administration in patients with bullous keratopathy. We recently reported $0.37 \mu \mathrm{g} / \mathrm{ml}$ of vitreous ofloxacin level in patients with healthy cornea following the same topical administration with the current study. ${ }^{13}$

In a previous study, in patients receiving two oral doses of $400 \mathrm{mg}$ ofloxacin, mean intravitreal level was found to be $1.75 \mu \mathrm{g} / \mathrm{ml} .{ }^{11}$ In the current study, a SRF ofloxacin level of 1.60 $\mu \mathrm{g} / \mathrm{ml}$ was attained following a single $400 \mathrm{mg}$ oral dose. It seems that SRF drug concentration is similar to that in vitreous. Oral administration of ofloxacin yielded an approximately four times higher SRF concentration than topical administration.

The ocular absorption of ofloxacin was shown to be increased in the inflamed eye. ${ }^{17} 18$ In this study we used patients having an operation for non-infective reasons. Diabetes is another factor that affects drug levels in ocular compartments. ${ }^{19}$ None of our patients was diabetic. On the other hand, combined use of same topical and systemic antibiotics increases vitreal drug level. ${ }^{20}$ In this study, the addition of oral ofloxacin to topical therapy increased SRF penetration about sixfold. Donnenfeld et $a l^{12}$ measured sevenfold more vitreous drug concentration following addition of oral ofloxacin to the topical therapy.

The most common organisms responsible for endophthalmitis are Staphylococcus epidermidis 50\%, Staphylococcus aureus 30\%, and streptococcal species $10 \% .{ }^{12}$ Bacillus cereus, Proteus mirabilis, and Pseudomonas aeruginosa together with Staphylococcus epidermidis are common causes of endophthalmitis after penetrating trauma. ${ }^{152122}$ We found a concentration of ofloxacin in SRF was above $\mathrm{MIC}_{90}$ for Staphylococcus epidermidis, Staphylococcus aureus, ${ }^{123}$ Proteus mirabilis, ${ }^{1}$ and Bacillus cereus ${ }^{6}$ in all patients following oral and combined application whereas in only two of nine patients after topical administration of the drug. Four patients in the oral and six patients in the combined ofloxacin group reached $\mathrm{MIC}_{90}$ for Streptococcus pneumoniae. Concentrations in three groups were below the therapeutic concentration required to inhibit Pseudomonas aeruginosa. A mean concentration of a drug in a particular compartment which is above $\mathrm{MIC}_{90}$ for a bacterium can not be interpreted as a guarantee of successful therapy 
there by members of that species, nor indeed does a concentration below it necessarily predict treatment failure. ${ }^{6}$

In conclusion, topical ofloxacin can penetrate SRF but it does not seem to be prophylactically effective against most ocular pathogens. In the posterior ocular inflammations with or without retinal detachment, either oral ofloxacin alone or combined therapy may result in higher drug levels in SRF.

This study was supported by a grant from the Scientific and Technical Research Council of Turkey (SBAG-COST B11477) and contributes to the goals of COST Project B1.

The authors have no proprietary or financial interest in any of the drugs or materials used in this study.

1 Drew RH, Gallis HA. Ofloxacin: its pharmacology, pharmacokinetics, and potential for clinical application. Pharmacotherapy 1988;8:35-46.

2 Just PM. Overview of the fluoroquinolone antibiotics. Pharmacotherapy 1993;13(suppl 2):4-17.

3 The Ofloxacin Study Group. Ofloxacin monotherapy for the primary treatment of microbial keratitis. A double-masked, primary treatment of microbial keratitis. A double-masked, therapy. Ophthalmology 1997;104:1902-9.

4 Gwon A, the Ofloxacin Study Group. Topical ofloxacin compared with gentamicin in the treatment of external compared with gentamicin in the treatment of

5 Akkan AG, Mutlu I, Özyazgan S, et al. Comparative tear concentrations of topically applied ciprofloxacin, ofloxacin, and norfloxacin in human eyes. Int $\mathcal{F}$ Clin Pharmacol Ther 1997;35:214-7.

6 Diamond JP, White L, Leeming JP, et al. Topical 0.3\% ciprofloxacin, norfloxacin, and ofloxacin in treatment of bacterial keratitis: a new method for comparative evaluation of ocular drug penetration. Br f Ophthalmol 1995;79: 606-9.

7 Durmaz B, Marol S, Durmaz R, et al. Aqueous humor penetration of topically applied ciprofloxacin, ofloxacin and tobramycin. Arzneimittelforschung 1997;47:413-5.

8 Akkan AG, Mutlu I, Özyazgan S, et al. Penetration of topically applied ciprofloxacin, norfloxacin and ofloxacin into the aqueous humor of the uninflamed human eye. 7 Chem other 1997;9:257-62.
9 Cekic O, Batman C, Totan Y, et al. Penetration of ofloxacin and ciprofloxacin in aqueous humor after topical administration. Ophthalmic Surg Lasers 1999;30:465-8.

10 Hanioglu-Kargi S, Basci N, Soysal H, et al. The penetration of ofloxacin into human aqueous humor given by various routes. Eur f Ophthalmol 1998;8:33-6.

11 Verbraeken H, Verstraete A, Van de Velde E, et al. Penetration of gentamicin and ofloxacin in human vitreous after systemic administration. Graefes Arch Clin Exp Ophthalmol (suppl) 1996;234:59-65.

12 Donnenfeld ED, Perry HD, Synder RW, et al. Intracorneal, aqueous humor, and vitreous humor penetration of topical and oral ofloxacin. Arch Ophthalmol 1997;115:173-6.

13 Çekiç O, Batman C, Yasar Ü, et al. Penetration of ofloxacin in human aqueous and vitreous humors following oral and topical administration. Retina 1998;18:521-5.

14 Basci NE, Hanioglu-Kargi S, Soysal H, et al. Determination of ofloxacin in human aqueous humor by highperformance liquid chromotography with fluorescence detection. F Pharm Biomed Anal 1997; 15:663-6.

15 Lesk MR, Ammann H, Marcil G, et al. The penetration of oral ciprofloxacin into the aqueous humor, vitreous, and subretinal fluid of humans. Am f Ophthalmol 1993;115: 623-8.

16 Richman J, Zolezio H, Tang-Liu D. Comparison of ofloxacin, gentamicin, and tobramycin concentrations in tears and in vitro MICs for $90 \%$ of test organisms. Antimicrob Agents Chemother 1990;34:1602-4.

17 Behrens-Baumann W. Absorption of topically administered ciprofloxacin, ofloxacin and gentamicin in the inflammed rabbit eye. Ophthalmologica 1996;210:119-22.

18 Gatti G, Panozzo G. Effect of inflammation on intraocular penetration of intravenous ofloxacin in albino rats. Antimicrob Agents Chemother 1995;39:549-52.

19 Cunha-Vaz J, Debreu JRF, Campos AJ, et al. Early breakdown of the blood-retinal barrier in diabetes. $\mathrm{Br} f$ Ophthalmol 1975;59:649-56.

20 Seal DV, Bron AJ. Infections of the eye. In: O'Grady F, Lambert HP, Finch RG, Greenwood D, eds. Antibiotic and chemotherapy. 7th ed. Edinburgh: Churchill Livingstone, 1997:788

21 David DB, Kirkby GR, Noble BA. Bacillus cereus endophthalmitis. Br f Ophthalmol 1994;78:577-80.

22 Alfaro DV, Davis J, Kim S, et al. Experimental Bacillus cereus post-traumatic endophthalmitis and treatment with ciprofloxacin. Br f Ophthalmol 1996;80:755-8.

23 Todd PA, Faulds D. Ofloxacin: a reappraisal of its antimicrobial activity, pharmacology and therapeutic use. Drugs 1991;42:825-76. 